\title{
Sand Bypassing Cost and Performance Database
}

\section{US Army Corps of Engineers}

by James E. Clausner

PURPOSE: The Coastal Engineering Technical Note (CETN) herein describes a database of cost and performance data from sand bypassing projects created as the initial step of developing an overall methodology for evaluating fixed sand bypass plant potential at coastal inlets.

BACKGROUND: Discontinuities in the shoreline, i.e., natural inlets, stabilized inlets and harbors, all interrupt the longshore transport of littoral sediments. At inlets and harbors used for navigation, most of which are stabilized with jetties, trapping of littoral sediments in jetty fillets, flood and ebb tidal shoals and the navigation channel cause two main problems. One problem is erosion of downdrift beaches. When sand is trapped in the navigation channel, the second problem is reduced navigation capabilities. Artificial sand bypassing, hereinafter referred to as sand bypassing or simply as bypassing, is the man-induced transfer of sand from the jetty fillets, shoals, or navigation channel to the downdrift beaches to mitigate the problems associated with the inlet or harbor.

The majority of sand bypassing is done in association with navigation dredging where sand removed from the navigation channel is placed directly on downdrift beaches or in the nearshore zone. Among U.S Army Corps of Engineers (Corps) coastal navigation projects, sand bypassing using fixed plants is relatively rare. This is also true from a worldwide perspective. Fixed-plant sand bypassing might be applied to more sites. However, the effort required to estimate costs and performance is significantly greater with fixed plants than simply modifying a navigation dredging contract for downdrift beach placement. The goal of the "Sand Bypassing Costs and Performance" Work Unit in the Corps Coastal Navigation and Storm Damage Reduction Research Program is to develop a standard methodology for calculating costs of fixed sand bypass systems using standard Corps cost-estimating techniques. Methods to predict performance of the fixed plant bypass systems (volume bypassed and bypassing rate), will also be provided. The costs and benefits of a fixed plant can then be directly compared to sand bypassing using conventional dredged and beach placement allowing Districts to relatively easily and at a modest cost to compare fixed plants with conventional dredging for maintenance of coastal inlets and downdrift beaches. In theory, this will facilitate selecting the optimum method for inlet maintenance, lowering costs and increasing benefits.

The Corps is now giving more emphasis to regional sediment management, i.e.; looking at sediment management over lengths of coast that includes multiple inlets can be hundreds of kilometers long. Within this context, sand bypassing becomes a more important concept. From a regional sediment management perspective, improved sand bypassing at inlets, whether done with conventional dredges or fixed plants, may provide significant benefits to the region as a whole and not just for a single inlet. 
As the initial step in this effort to create a methodology for readily comparing fixed plant bypassing with bypassing using dredges; cost, performance and other relevant data on bypass projects were collected. During the data collection effort, creation of an electronic database appeared to be a logical method to store information. It also occurred to the author that users interested in bypassing information could also use the database as a stand-alone product.

The remainder of this technical note describes the projects in the database, the categories of data included, and some details on specific data types collected in each category. The tech note concludes with some details on the database and plans for release.

PROJECTS SELECTED: Time and funding constraints limited the number of projects placed in the database. However, additional projects could be added in the future. An attempt was made to include a range of project types from various locations around the United States and an innovative fixed bypass plant in Australia. Projects that bypass sand using fixed plants and those that bypass using dredges were included. For the dredging-based bypass projects, sites with a specific structure for trapping sand (e.g., a weir jetty) were included along with projects that have jetties only.

The following tables show various means to group and categorize the projects. Table 1 lists the fixed plants and their associated prime movers. Table 2 lists the dredging-based bypass projects, their associated structures for bypassing (if any) and whether bypassing is accomplished regularly by a dedicated dredge or periodically by a contract dredge. Table 3 lists all projects in the database, sorted by the volume of sand bypassed on an annual basis. The volumes presented are rounded to the nearest $1,000 \mathrm{cu}$ yd.

After the projects were chosen, pertinent data for the database were identified along with a point of contact (POC) for each project. A contractor then contacted each POC with a request for data. In general the POC provided some overall details and was asked to provide documents that could be reviewed to extract the desired data. The contractor subsequently extracted the required data from references provided by the project POCs.

\section{Table 1}

Fixed Bypass Plants

\begin{tabular}{|l|l|l||}
\hline \hline Project Name & Location & $\begin{array}{l}\text { Prime Mover/Deployment } \\
\text { Scheme }\end{array}$ \\
\hline \hline Indian River Inlet & Bethany Beach, DE, USA & Single Jet Pump/Crane \\
\hline Lake Worth Inlet & Palm Beach, FL, USA & $\begin{array}{l}\text { Single Pure Suction Pipe/Pivoted } \\
\text { Boon }\end{array}$ \\
\hline Nerang River Entrance & Southport, Queensland, Australia & 10 Jet Pumps fixed to trestle \\
\hline
\end{tabular}




\section{Table 2}

Dredge-Based Bypass Projects

\begin{tabular}{|l|l|l|l||}
\hline Project Name & Location & Dredging Mode & Bypass Structure \\
\hline \hline Canaveral Inlet & Cape Canaveral, FL, USA & $\begin{array}{l}\text { Periodic dredging by contract } \\
\text { plant }\end{array}$ & None \\
\hline $\begin{array}{l}\text { Channel Islands } \\
\text { Harbor }\end{array}$ & Oxnard, CA, USA & $\begin{array}{l}\text { Periodic dredging by contract } \\
\text { plant }\end{array}$ & $\begin{array}{l}\text { Detached } \\
\text { breakwater/sediment trap }\end{array}$ \\
\hline Masonboro Inlet & $\begin{array}{l}\text { Wrightsville Beach, NC, } \\
\text { USA }\end{array}$ & $\begin{array}{l}\text { Periodic dredging by contract } \\
\text { plant }\end{array}$ & Weir jetty \\
\hline Perdido Pass & Orange Beach, AL, USA & $\begin{array}{l}\text { Periodic dredging by contract } \\
\text { plant }\end{array}$ & Weir jetty \\
\hline Rudee Inlet & Virginia Beach, VA, USA & $\begin{array}{l}\text { Regular dredging by dedicated } \\
\text { dredge, supplemented by } \\
\text { periodic dredging by contract } \\
\text { plant }\end{array}$ & Weir jetty \\
\hline Santa Cruz Harbor & Santa Cruz, CA, USA & $\begin{array}{l}\text { Regular dredging by dedicated } \\
\text { dredge }\end{array}$ & None \\
\hline
\end{tabular}

\begin{tabular}{|l|c|}
\hline \multicolumn{2}{|l|}{$\begin{array}{l}\text { Table 3 } \\
\text { Annual Production of Bypass Projects }\end{array}$} \\
\hline \hline Project Name & $\begin{array}{l}\text { Average Annual Bypass } \\
\text { Volume (cu yd) }\end{array}$ \\
\hline Canaveral Harbor & 512,000 \\
\hline Channel Islands & $1,050,000$ \\
\hline Indian River Inlet & 91,000 \\
\hline Lake Worth Inlet & 135,000 \\
\hline Masonboro Inlet & 360,000 \\
\hline Nerang River Entrance & 600,000 \\
\hline Perdido Pass & 175,000 \\
\hline Rudee Inlet & 135,000 \\
\hline Santa Cruz Harbor & 143,000 \\
\hline
\end{tabular}

PROJECT DATA INCLUDED IN THE DATABASE: The data identified as required to evaluate cost and performance of sand bypassing projects are described in the remainder of this section. For most projects, there were some data gaps. Time and funding limits precluded any analysis in this initial phase. The only real processing was to convert costs to 1999 dollars.

Project Overview: This section of the database provides project location, a site map, the problem to be solved by bypassing, describes success criteria for the bypass project if any (e.g., a certain number of cubic yards bypassed, a specific navigation channel depth maintained, etc.), and the type of plant used for bypassing. 
Inlet Physical Characteristics: This section includes: inlet width, cross-sectional area, tidal prism, navigation channel depth and width, ebb shoal information, and sediment grain size data.

Bypass System Overview: This section includes dates of operation, source of bypassed sediments, system design capacity, location of bypass sediment placement, operating details for fixed and dredge-based systems. For fixed systems the database includes, operating schedule, frequency, equipment used, number of employees, type of system, prime mover, location, configuration, pipeline lengths, pump pressures and instrumentation. For dredge-based systems the operating frequency and average duration of the dredging operation are included. For bypassing using cutterhead dredges, the typical dredge size (discharge line diameter) and power used during bypassing are included. For systems based on hopper dredges, data included are the hopper volume, typical load, installed power, length and diameter of discharge line if direct pump-out is used.

Coastal Process Data: This section includes sediment transport data (left, right, net, and gross transport), maximum hour, daily and monthly transport rates, sediment volumes in the updrift fillet, ebb and flood shoals, volume naturally bypassed, downdrift erosion rate, tide range and links to wave data.

Wave Data: From the coastal processes form of the database there is a link to an Excel spreadsheet with summarized wave data. The wave data are generally from the nearest WIS (reference) site. Included are the Hm0, Hm0 max, and Tp max for each $22.5 \mathrm{deg}$. Also included are the mean $\mathrm{Hm0}$ by month/year for each year in the WIS database. Finally, mean spectral wave height $(\mathrm{m})$, mean peak wave period (s), most frequent 22.5 (center) direction band (deg), standard deviation of $\mathrm{Hm} 0(\mathrm{~m})$, standard deviation of Tp (sec), largest $\mathrm{Hm} 0(\mathrm{~m})$, Tp (sec) associated with largest $\mathrm{Hm} 0$, peak direction (deg) associated with largest $\mathrm{Hm} 0$, date of largest $\mathrm{Hm0}$ occurrence, and a link to the CHL web site for additional data are included.

System Performance Data: This section defines what defines the success criteria and how they have or have not been met. For many systems, specific criteria to define success were not defined. Also in this section are data on updrift and downdrift beach profile taken to monitor adjacent beaches, including profile spacing, and frequency or dates of beach profiles. Also noted is if nearshore placement was used, whether or not bathymetry data have been analyzed and the dates the surveys were collected.

Site Photos: For each project at least an image is included. At a minimum, this is an oblique aerial photo. Often a line drawing providing a plan view of major components is included.

Points of Contact: The points of contact include both a Corps and local contact where appropriate. A full address, phone numbers and e-mail are included.

References: Pertinent references reviewed in creating the database are included. The references were in most cases provided by the points of contact.

Cost Data: From within the database, a link to an Excel spreadsheet with detailed cost data is provided. The amount of detail in the cost data varies from project to project. For contract dredging projects, the mob/demob cost and a unit price and a total volume and cost are provided. 
For fixed plants, at a minimum construction cost and annual operating cost are provided. For Indian River Inlet detailed costs are included with a breakdown that includes employee salaries, electricity, fuel for the crane, repairs, and major equipment replacement. For Nerang, cost data included salaries, electricity for plant operations, and repairs and maintenance. A second data request for more detailed cost data is planned.

Costs were converted to 1999 dollars using the Civil Works Construction Cost Index System (CWCCIS) USACE Engineer Manual EM 1110-2-1304, September 1998.

Production Data: From within the database, a link to an Excel spreadsheet with project production data is provided. For every project, an annual volume removed or placed is provided for each year of data. For some of the dredge-based systems the duration of the transfer is known, allowing transfer rates over various time periods to be computed. For the fixed plants in some cases, average transfer rates are already computed or could be computed from available data. A second data request for more detailed production data is planned.

Glossary: A glossary of terms focusing on those used in the database, emphasizing definitions related to cost and production are included.

DATABASE AVAILABILITY: In late CY99, the data in the database will be reviewed by the project POCs. Once they have verified the information is correct, they will be given the opportunity to fill in any data gaps. After this new data is entered into the database, it will be made available to the Corps. At present we are considering several options for releasing the data, including supplying individual CDs and the Internet, in which case the data will be publicly available. A decision is expected in early CY00 on the method(s) for data release.

If released by $\mathrm{CD}$, the original data will most likely be in a write-protected format. The user can choose to modify the Excel spreadsheets and save them to a local file on their PC. The capability to add additional data will be considered.

If the database is released via the Internet, a version that does not require the users to have Access is planned. This executable version of Access will allow the user to review the data in the database.

DATABASE SOFTWARE AND PC REQUIREMENTS: The sand bypass project cost and performance database is written for Microsoft Access 97@. Wave, cost and production data are provided in Microsoft Excel 97( ) that can be accessed from within the database. Considerable effort has been made to make the database easy to use, requiring minimum experience with Access $($ ).

Minimum suggested computer hardware capabilities are a $166 \mathrm{MHz} \mathrm{CPU}$ with $32 \mathrm{Mbytes}$ of RAM and 1 Mbyte of video memory.

FUTURE PLANS: During FY00, ERDC staff will work with cost engineering experts from the Jacksonville District (SAJ) to develop the methodology for computing costs for fixed plants of fixed plants and estimating performance. 
ERDC/CHL CETN II-41

December 1999

ADDITIONAL INFORMATION: For additional information, contact Mr. James Clausner (Voice: (601) 634-2009, e-mail: clausnj@wes.army.mil).

This CETN should be cited as follows:

Clausner, J. (2000). "Sand bypassing cost and performance database," ERDC/CHL TN-II-41, U.S. Army Engineer Research and Development Center, Vicksburg, MS. http://chl.wes.army.mil/library/publications/ceth/ 